\title{
AN ANALYSIS OF SPEECH ACT USED IN PETER RABBIT MOVIE
}

\author{
Revina Dwi Orizka, Ayu Oktaviani, Agus Triyogo \\ revinadwiorizka@gmail.com, damerayu13@gmail.com, agustriyogo@gmail.com \\ STKIP-PGRI Lubuklinggau
}

\begin{abstract}
This study aimed to find out and describe the forms of speech act used in Peter Rabbit Movie. The method used qualitative design with descriptive method. Data collection techniques in this study was using the human instrument. While human instrument meant data collected by the writer itself. Techniques for analyzing the data with step by step: watched the movie, found out the speech act in dialogue of the movie, captured and identification the dialogues, and noted down the data based on the classification. The result showed, in Peter Rabbit movie the writer found 4 out of 5 classifications. There were 55 dialogues that it was representatives, 21 dialogues that it were commissive, 90 dialogues that it were directives, 61 dialogues that it were expressive.
\end{abstract}

Keywords: Speech act, peter rabbit, movie

\section{INTRODUCTION}

Language was one of the most important parts in social environment, for example many important activities in social environment, such as learning, make a friend, build relation and many others. According to Cook (2003:03), "language is at the heart of human life". People used language as a tool to do many things. It meant that language be a part that very important in human's life to communication among people in the world, and also becomes unifying force in every sector of human's life.

There were many kinds of languages which people used to communication, one of them is pragmatic. Pragmatic was a study about speaker meaning. In other word, it defined about the meaning of the context between the speaker and hearer. According to Yule (1996:04), the advantage of studying language via pragmatic is that one can talk about people's intended meanings, their assumptions, their purposes or goals, and the kinds of action that they are performing when they speak. In pragmatic, the hearer does not only understand the meaning of speaker by speaker, but the listener also understands the context for interpreting an utterance. Pragmatic had many types of study, such as deixis and distances, reference and inference, presupposition and entailment, politeness and interaction, speech act and event, and others. In this study the writer only focused on speech act.

Speech acts was the study how to do things with words, most of activity in daily life people use to do thing with word such as when people ask someone for help or make a statement and many others. Yule (1996:47), stated that "an action that is performed by utterances is called speech acts". It meant that the words had the same functions when people perform something using physical action. According to Lese (2017:69), "there are various physical action derived from social actions, for example: to walk, to embrace, opening the window, jumping, picking up suitcase, which, in a stage convention, represents a specific purpose". In addition, speech act was found in various types of 
communication, it could be daily conversation, formal meetings, speeches, and others. To understand more about what the classifications of speech acts were, the following Yule's theory in five classifications of speech acts: representatives, directives, commissive, declarative, and expressive. All the kinds of speech acts are usually used by people to communication each other.

Almost of people have different speech acts in every conversation. It depended to people need, other speakers, environment and other. For example, an actor or actress in movie they used speech acts to express what they need, want or something else, to show the meaning of their conversation or dialogue. There were many several of speech acts that find out that doing by actor or actress in a movie. There were many types of movies including horror, comedy, drama, and animate. Animate was process of creating motion effects or shape changes that occur over time. According to Merono (2014:04), "animate is describe the action as the capacity to bring to life". And also, there were many types of animate movies one of them was live-action animate. A live-action animated movie is one that combines live action filmmaking with animation. One of the live-action animated movie entitled Peter Rabbit.

Peter Rabbit was a 2018 liveaction/computer-animated comedy film directed by Will Gluck and written by Rob Lieber and Gluck. Moreover, Peter Rabbit movie display many interesting actions and displays the genius of Peter Rabbit in dealing with the problems that occurs. This movie receives many awards such as Australian Academy of Cinema and Television Arts (AACTA) Award 2018 nominated Best Production Design and Best Visual Effects or Animation, Australian Screen Sound Guild (AASG) 2018 nominated Andrew Plain Award for Best Film Sound Editing and Golden Trailer Award 2018 nominated Best
Animation/Family Poster. The writer would like to analyze the Peter Rabbit movie because the movie has more than one of speech acts and it was a live-action animated movie latest that has no one writer analyzed the movie. And then, the movie has a light story to understand for students and lecturers.

Based on the explanation above, the writer was interested in doing the study about speech acts in Peter Rabbit movie. The writer interested to choose speech acts in Peter Rabbit movie as the object of this study because speech act can be found in the general communication in daily conversation on the Peter Rabbit movie, it meant that it could be easy for the student to learned about speech act from the conversation in this movie. Then, the writer decided to choose the tittle of this study as "Analysis of Speech Acts Used in Peter Rabbit Movie."

\section{RESEARCH METHOD}

In this research, the writer would apply qualitative research. According to Latief (2014:75), qualitative research is a process of inquiry aimed at understanding human behavior by building, complex, holistic pictures of the social and cultural setting in which such behavior occurs.

In collecting the data, there are some steps that used by the writer in colecting the data of the study. To collect the data of the study, the writer used document method. According to Arikunto (2005:244), document method is looking for data about the items, such as transcription, book magazine and newspaper. There were steps in collecting the data through document method, they were:

1. Watched the movie.

2. Found out the speech act in dialogue of the movie.

3. Captured and identification the dialogues of speech act spoken by all characters in the movie. 
4. Noted down the data based on the writer's classification that writer found in the movie.

The source of the data took from speech act analysis used in Peter Rabbit movie dialogues. This study limited the data by analyzing the classifications of speech acts spoken by all characters from began of the movie until sixty minutes of the movie's duration.

Meanwhile in this research, the instrument of the data was human instrument. Peredaryekno (2013:03) stated that equally, research appliance is researcher alone. The data was collected by the writer itself as the instruments of the study.

After finishing the procedure of data collection, the researcher analyzed the data by identifying, classifying, describing, concluding the data. In analyzing the data, the writer collecting, selecting and clarifying the suitable of speech acts with the method and relevant concept, especially by using Yule's theory. In this study, the process of collecting the data was done through the following steps:

1. Watched the movie throughly.

2. Read the dialogue on the capture and the script carefully.

3. Analyzed the classifications of speech acts based on Yule's theory.

4. Described the classifications of speech acts that found out in Peter Rabbit movie.

5. Drew a conclussion.

\section{RESULT AND DISCUSSION}

\section{Result}

The writer found 4 classification of speech act in that movie, such as representative, commisive, direction and expressive. The total number of them was 227. As stated before in the previous chapter, in analyzing the data, the procedure used by the writer were analyzing and describing the classification of speech act. The result of the data analysis was taking from analysis process of overall data, concerning speech acts in Peter Rabbit movie dialogue.

\section{Representative}

In representative the result was subdivided into four types, which were assertion, fact, description, and conclusion. The writer found 28 in assertions, 19 in facts, 5 for descriptions, and 3 in conclusions.

\section{Commissive}

In commissive the result was subdivided into three types, which were promise, threat and warning. The writer found 12 in promises, 3 in threats and 6 for warnings.

\section{Directive}

In directive the result was subdivided into four types, which were command, suggestion, request and order. The writer found 78 in commands, 2 in suggestions, 9 in requests and 1 for order.

\section{Expressive}

In expressive the result was subdivided into four types, which were apology, pleasure, like, dislike, thanking, joy, welcoming, congratulating, complimenting, sorrow and pain. The writer found 20 in apologies, 6 in pleasures, 3 in likes, 7 in dislikes, 12 in thankings, 4 in joys, 4 in welcomings, 1 in congratulating, 2 in complimentings, 1 in sorrow and 1 for pain

\section{Discussion}

In this subchapter, it will be discussed about all the finding. Based on the finding above, the classifications of speech act based on the theory of Yule (1996:53), defined that there are five types of general functions performed by speech acts, such as representatives, declarations, commissive, directives, and expressive. The writer found classifications of speech act which consist of representative, commissive, directive and expressive. 


\section{a. The sample of Representative}

Representative was a according to Yule (1996:53) representatives are those kinds of speech acts that state what the speaker believes to be the case or not, such as statement of fact, assertions, conclusions and descriptions. In representative the writer found 28 in assertions, 19 facts, 5 descriptions and 3 that consist in conclusions. The sample at each of them:

For assertion writer found $\mathrm{Mr}$. McGregor's dialogue that said "This is my garden." The dialogue, told that in the morning situation Bea had been being calm Mr. McGregor down for made sure that Mr. McGregor didn't want to kill the rabbit. But Mr. McGregor immediately stated that "This is my garden.". Mr. McGregor's statement "This is my garden.". this utterance was to confirm what he believed that according him that was his garden, so it was representative because the speaker stated a confident statement of assertion.

For fact the writer found in Benjamin's dialogue that said "This guys is so much faster than the old one." The situation of statement above was when Benjamin and Peter Rabbit run away from Thomas so that they didn't caught by him. In fact, Thomas was so much faster than Mr. McGregor when he tried to caught Peter Rabbit and Benjamin. So, the statement "This guy is so much faster than the old one." meant the fact what the speaker feel. This utterance was the fact that Benjamin believed.

And then, for description the writer found in Peter Rabbit's dialogue that said "Which is technically 26 because they go." this utterance meant description that Peter Rabbit explained. From the dialogue above Cotton-Tail believed that she have 11 more ribs but then Peter Rabbit described what he believed as a fact about that ribs. The utterance Which is technically 26 because they go. was description about that ribs it meant that Peter Rabbit described about the ribs.

The last, for conclusion the writer found in Peter Rabbit's dialogue that said "So that could mean only one thing." this utterance was a conclusion from Peter Rabbit's opinion. The dialogue above Mopsy was asking what Peter Rabbit opinion, then Peter Rabbit explained about his opinion then he concluded. It showed in the dialogue that Peter Rabbit said " $\underline{\mathrm{s} O}$ that could mean only one thing." So, it meant a conclusion from his opinion.

\section{b. The samples of Commissive}

Commissive was according to Yule (1996:54) Commissives are those kinds of speech acts that speakers use to commit themselves to some future action. They express what the speaker intends, such as promise, threat, warning, and refusal. In commissive the writer found 12 in promises, 3 in threats and 6 for warnings. The samples at each of them:

For promise the writer found in Bea's dialogue "I'll promise I'll always be here for you." The situation of the dialogue was raining and then Peter Rabbit was remember about his family because he saw the Bea's painting in the room that they was taking shelter from the rain, so in the Bea's painting there was Peter's family that made he's sad when he saw it. This utterance meant that Bea promise that would always for Peter Rabbit and others.

The sample for threat, the writer found in Mr. McGregor's dialogue that said "Rabbit, I'm gonna put you in a pie." The situation of the dialogue that Mr. McGregor was mad at Peter Rabbit because Peter Rabbit stole his fruits and vegetables in his garden, and then when Peter Rabbit want to run away from his garden but Peter Rabbit but unfortunately Peter Rabbit caught by him. So this utterance meant that he would like to put Peter Rabbit in a pie as the threat.

Next the sample of warning, the writer found in Mopsy's dialogue that said "Explosive, Explosive." The situation from 
the dialogue showed that Mopsy saw that there were many explosives that entered their house. Mopsy warned to others that someone wanted to blow up their house. So, the utterance above meant a warning and Mopsy commit to others to be careful because there was the explosive that entered their house.

\section{c. The samples of Directive}

According to Yule

(1996:54)

Directives are those kinds of speech acts that speakers use to get someone else to do something. They express what the speaker wants, such as commands, orders, requests, suggestions, etc. for directive the writer found 78 in commands, 2 in suggestions, 9 in requests and 1 for order.

The sample of command, the writer found in Cotton-Tail's dialogue that said, "Get out of there." Situation of the dialogue was panic because Peter Rabbit was chasing by Mr. McGregor in his garden. The utterance showed that Cottontail wanted Peter Rabbit to gone from there because Mr. McGregor tried to kill him.

Then, the sample of suggestion, the writer found in Bea's dialogue that said, "You must stop going in there." This utterance meant that Bea instructed Peter Rabbit and other to stop went to $\mathrm{Mr}$ McGregor's Garden. From the dialogue above showed that Bea suggested that listener to stop what listener do.

The sample of request, the writer found in Bea's dialogue that said " Just, please, don't be like the nasty old man." The Situation of the dialogue was Bea had been making conversation with Thomas but then she asked a request to Thomas that he shouldn't be like Mr. McGregor. The utterance meant that Bea wanted to Thomas didn't do like Mr. McGregor had done

The sample of order, the writer found in Pigling's dialogue that said, "I'll just take one." The situation of the utterance was in Peter Rabbit's party that Pigling want to take one food. So, it meant that
Pigling ordered one food that Tommy offered to Pigling.

\section{d. The sample of Expressive}

Expressive according to Yule (1996:53) Expressive are those kinds of speech acts that state what the speaker feels, such as pain, like, dislike, joy or sorrow, complimenting, congratulating, thanking, and welcoming. The writer found 20 in apologies, 6 in pleasures, 3 in likes, 7 in dislikes, 12 in thanking's, 4 in joys, 4 in welcoming's, 1 in congratulating, 2 in complimenting's, 1 in sorrow and 1 for pain. The sample at each of them:

The sample of apologies, the writer found in Peter Rabbit's dialogue that said, "I'm sorry." The situation of dialogue was when Benjamin caught by Thomas in Thomas's Garden then Peter Rabbit and his sisters was helping Benjamin. The utterance meant that Peter Rabbit apologized about his fault to Benjamin that made Benjamin could've been killed. He apologized about his fault to Benjamin.

Next the sample of pleasure, the writer found in Thomas's dialogue that said, "It's lovely to see you." The situation of the dialogue it was Bea accidentally met Thomas in the city. From the dialogue by Thomas said that "It's lovely to see you." It meant that Thomas had a pleasure to meet Bea there.

Then, the sample of like, the writer found in Peter Rabbit's dialogue that said, "I like her like a mother." The situation of dialogue of Peter Rabbit talked about what Peter Rabbit all the thing about then he explained that it's only about their garden and because he loves Bea like a mother. Peter Rabbit expressed that he loves Bea meant about like.

The sample of dislike, the writer found in Bea's dialogue that said, "I guess I don't like people." The situation was when Thomas said that he had tendencies and then Bea also said that everyone had tendencies next, she said that she didn't like people it meant the sentences showed 
about dislike. This statement showed that she disliked about other people.

The sample of thanking, the writer found in Pigling's dialogue that said, " $\underline{B u t}$ thank you for the party." From the dialogue above Pigling was invited by Peter Rabbit to their party and then Pigling made a conversation with Peter Rabbit. Then the conversation was talking about how Peter Rabbit can vanquish Mr. McGregor. After heard the explanation from Peter Rabbit then Pigling's utterance meant that he thanked to Peter Rabbit about the party.

Next the sample of joy, the writer found in Mopsy's dialogue that said "Wow. Classy." The situation of the dialogue by Mopsy it was when she and others went to city, and she looked around her and she enjoy it. From the expression of her that she expressed about her feel when she saw the city. Mopsy showed that she felt enjoy the surrounding scenery.

Then, the sample of welcoming, the writer found in Thomas's dialogue that said, "Welcome to Harrods." dialogue above showed that Thomas was welcoming the visitor to the department store the place that he just fired from there said with a silly utterance, but he still welcoming the visitor with sound relax.

The sample of congratulating, the writer found in Thomas's dialogue that said "Bennarma. Congratulation." Thomas gave the congratulating for Bennarma that he didn't want to get it. The dialogue above Thomas told the congratulated for the Bannerma even thought that Bennerman didn't want what he got. The statement from Thomas "Bannerma. Congratulation." Was an expression of praise for Bennerma's achievement for the act of congratulating by Thomas.

The sample of compliment, the writer found in Triplet that said " $A w$." The situation of the expressive above was when Flopsy, Mopsy and Cottontail heard and saw the romantic scene between Bea and Thomas in the car. They were expressing a compliment when they saw and heard something romantic from Bea and Thomas. The utterance above showed the speakers felt expression of admiration from something romantic that Bae and Thomas doing.

The sample of sorrow, the writer found in Thomas's dialogue that said, "That's incredibly especially accurate, and a little disappointing." the situation that Thomas wanted to know about what Bea had said to Chris about Thomas. But when Thomas known what Bea had said then Thomas had told the sorrow that he has disappointed to hear the information. The dialogue of "That's incredibly especially accurate, and a little disappointing" showed that Thomas was really express his sorrow to hear the information by Chris. $\mathrm{He}$ has disappointed to hear the accurate imformation from Chris.

The last, the sample of pain, the writer found in Flopsy's dialogue that said" Aw!!" The situation of the dialogue above told that Mopsy wanted to make sure that they were real. To prove it, she hit Flopsy's head by her hand, it made Flopsy make a sound " $A w$ !!", it meant that Flopsy feel pain when she made a sound " $A w$ !!". So, the sound of " $A w$ !!" meant that Flopsy felt pain about her head. She was hitting by Mopsy and then she felt pain in her head.

\section{CONCLUSION AND SUGGESTIONS}

From the finding it has been found and discussed in the previous chapter, it can be concluded the result showed, in Peter Rabbit movie the writer found 4 out of 5 classifications.

There were 55 dialogues that it was representatives, they were 28 in assertions, 19 in facts, 5 for descriptions, and 3 in conclusions. Those cause happened in this movie because representative talks about truthfully, declaratives that attempt to change the world.

Then, 21 dialogues that it was commissive, they were 12 in promises, 3 
in threats and 6 in warnings. Those cause happened in this movie because commissive was commit the speaker for doing something in the future.

There were 90 dialogues that it was directives, they were 78 in command, 2 in suggestion, 9 in request and 1 in order. Those cause happened in this movie because in directives the speaker tries to make listener perform the action.

Last 61 dialogues that it was expressive, they were 20 in apology, 6 in pleasure, 3 in like, 7 in dislike, 12 in thinking, 4 in joy, 4 in welcoming, 1 in sorrow, 1 in pain, 2 in congratulating and 2 in complimenting. Those cause happened in this movie because in expressive the speaker must express their feeling about the situation.

Based on the conclusion above some suggestion could be presented for the students, reader, and the researcher herself as follow, for the students. The results of this research indicated that speech act important in learning proses. For the writer, since this research still lack many things and far for being perfect. The writer expects that there will be another researcher who will investigate relating on speech acts. The writer also hopes this study will be useful and can be used as a reference to the others who will be conduct and develop a similar study.

For teacher especially to English teacher, this study was expected to provide an additional teaching material in pragmatic study, especially about speech act. The teacher can use the example of speech acts in this study as a reference in teaching of speech acts.

For the other researcher. There are many aspects that can be analyzed about speech act. The other researcher are expected to analyze the other aspects that related to the speech act and the result of this research may be used as early information to conduct further researcher.

For the researcher herself. The results of this research can give more information about speech act. In additionally, the information can motivate the researcher to study more about learning strategy.

\section{REFERENCES}

Arikunto, S. (2005). Manajemen Penelitian. Jakarta: PT. Rineka Cipta.

Austin, J.L. (1962). How to Do Things With Words. Oxford: Clarendom Press. Retrieved from https://pure.mpg.de.

$$
\text { (1975). How to Do Things }
$$
With Words. Cambridge, Massachusetts: Harvard University Press.

Church, R,. M. (2001). The Effective Use of Secondary Research. Learning and Motivation. 33. 32-34. Retrived from http://www.idealibrary.com.

Cook, G. (2003). Applied Linguistic. Oxford: Oxford University Press.

Creswell, J., W. (2009). Research Design: Qualitative, Qualitative, and Mixed Methods Approaches (3rded.). California: Sage Publications Inc. Retrieved form https://www.pdfdrive.com/john-wcreswell-research-design_qualitative-quantitative-and-mixedmethods-approachesd24960021.html.

Latief, M. A. (2014). Research Method on Language Learning an Introduction. Malang: IKIP Malang.

Merono, L. (2014). The Creation Process of 2D Animated Movies. Retrieved fromhttps://www.edubcn.cat/rcs_gen e/treballs_recerca/2014-2015-02-4TR_baixa.pdf 
Peredaryenko, M., S. \& Crause, S., E. (2013). Calibrating the Human Instrument: Understanding the Interviewing Experience of Novice Qualitative Researcher. The qualitative report, 18(43), 1-17. Retrieved from https://nsuworks.nova.edu/tqe/vol18/ iss $43 / 1$

Searle, J. R. (1969). Speech act: An essay in the Philosophy of Language. London: Cambridge University Press.

(1976). A classification of Illucationary Act. Cambridge: Cambridge University Press.

. (1976). Speech Act. An Analysis in Philosophy of Language. Cambridge: Cambridge University Press.

Yule, G. (1996). Pragmatics. Oxford: Oxford Univerity Press. Retrieved from

https://www.scribd.com/doc/116375 00/Yule-George-Pragmatics. . (2006). The Study of Language. Cambridge, UK: Cambridge University Press. Retrieved from http://www.slideshare.net/mobile/Ni sarKhan13/the-study-of-language4th-edition. 